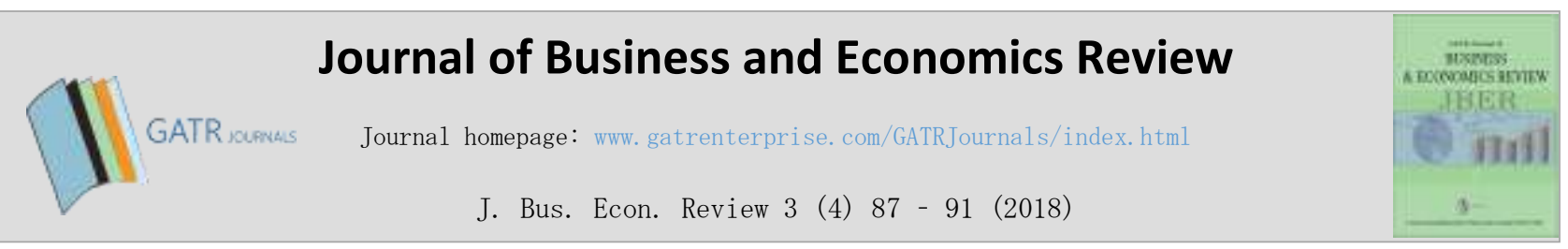

\title{
Economic Analysis of Sea Shellfish as a Basic Material for Making Shellfish Souvenirs
}

\author{
Nanik Hariyana, ${ }^{1}$ Hendra Syahputra, ${ }^{2}$ Minullah $^{3}$ \\ ${ }^{1}$ Lecture, Faculty of Economic, University of Abdurachman Saleh Situbondo, Indonesia \\ ${ }^{2,3}$ Lecture, Faculty of Economic, University of Abdurachman Saleh Situbondo, Indonesia
}

\begin{abstract}
Objective - Indonesia consists mainly of waters and is therefore rich in various marine products, either in the form of fish or other resources. One such property is shells. The selection of sea shells as a business material is based on the use of sea shells for daily needs. The price of sea shells is relatively cheap and the use of sea shells as a material for making souvenirs and handmade ornaments is a promising business prospect.

Methodology/Technique - In planning this activity, the location of the marketing of the product is the central region of the city of Semarang. This area is home to a large source of sea shells and there is a lack of souvenir businesses using sea shells to make their products.

Findings - The results of the study show that seashell businesses located in Situbondo Regency are experiencing good growth in recent years.

Novelty - The research is one of few on seashell business in the context of Indonesia. This research opens the ways to bring more investment and growth awareness.
\end{abstract}

Type of Paper: Empirical.

Keywords: Sea Shells; Cost Structure; Benefits; Business Efficiency, Indonesia.

JEL Classification: O10, O12, O13.

\section{Introduction}

\subsection{Background}

Today, many businesses are engaged in various fields, ranging from home businesses, to macro business. The types of goods produced by businesses also vary, ranging from food to clothing to household items, and the price of these good also tend to vary quite significantly. Hence, it is important for new business owners to be creative in the products they choose to market.

\footnotetext{
* Paper Info: Revised: July 22, 2018

Accepted: December 10, 2018

* Corresponding author: Nanik Hariyana

E-mail: hariyana.nanik@yahoo.com

Affiliation: Lecture, Faculty Economic, University of Abdurachman Saleh Situbondo, Indonesia
} 
One type of business is the production of souvenirs made from sea shells. These items may include accessories, decorations or household items. An individual with experience in producing these kinds of items may choose to open their own business. The more experienced you are, the more value you can add to a new business. This may even be a type of business that one can manage from the comfort of their own home. This type of business does not require a large amount of capital to establish and profit can be generated relatively quickly Sathiadhas, R., \& Aswathy, N., 2004.

The ornament and accessory industry is quite large, and many retailers can find success in this industry. The business that is established for the purpose of this study produces household items made from sea shells, such as wall clocks and decorations for tissue boxes. In addition to producing ready-to-use goods, the business also produces semi-finished goods that can be combined with other items or accessories.

\subsection{Research Questions}

Based on the above description the following problems are addressed in this study:

1. What is the return on investment (ROI) of the seashell business in Situbondo over the last 3 years?

2. Do factors such as Total Assets (TA), Net Sales (NS), and Earning After Taxes (EAT) have a significant effect on return on investment (ROI) in a seashell business in Situbondo Regency?

3. Do factors such as Total Assets (TA), Net Sales (NS), and Earning After Taxes (EAT) simultaneously have a significant effect on return on investment (ROI) in a seashell business in Situbondo Regency?

4. Of the 3 factors, which has the most influence on the return on investment (ROI) of a seashell business in Situbondo Regency?

\section{Literature Review}

\subsection{Economic Development and Growth}

One very important indicator of economic development is economic growth. Economic development and economic growth are different concepts. Economic development in general is a process that causes an increase the real income per capita of a country's population accompanied by an institutional system. Economic growth is defined as an increase in GDP or GNP regardless of whether the increase is greater or smaller than the level of population growth, or whether changes in economic structure occur or not (Arsyad, 1999).

\subsection{Sea Shell Business as a Base For Making Shellfish Souvenirs}

Shellfish are aquatic animals such as soft-bodied animals (mollusks). In the broadest sense, shellfish refers to all mollusks with a pair of shells (Bivalvia). With this understanding, it is more appropriate to refer to the as shellfish. The word "shell" can also mean all shellfish whose life is attached to an object.

\subsection{Consumer Behavior and Purchasing Decisions}

Engel (1995, p. 3) states that consumer behavior is the activities of an individual directly involved in obtaining and consuming goods or services, including the process of decisions that precede and follow this action.

\subsection{Return on Investment (ROI)}


According to Sartono (2001, p. 119), profitability refers to the ability of a company to earn profits in relation to sales, total earning assets and capital. This profitability ratio will provide an overview of the effectiveness of a company's management.

\section{Research Methodology}

In accordance with the research objectives, this research uses Explanatory Research (explanation). This explanatory study highlights the causal relationship between the variables and aims to test the hypothesis. With respect to the population and the determination of samples and the mainstay of questionnaires as instruments for collecting data, this study can also be classified as empirical. These types of research are used to explain the relationship between After taxes (EAT), Net Sales (NS), and Total Assets (TA) with the existing Return on Investment (ROI) of Cooperative Women in Situbondo Regency.

$$
F=\frac{R^{2} / K}{\left(1-R^{2}\right) /(n-k-1)}
$$

\section{Results and Discussion}

The results show that seashell businesses located in Situbondo Regency are experiencing good growth. Based on this, seven cooperatives are described in Table 4.1 below.

Table 4.1 List of Activists of Active Shellfish in Situbondo Regency

\begin{tabular}{|c|c|c|c|}
\hline NO. & NAME OF PENNGUSION OF SHELLS & VILLAGE & SUB-DISTRICT \\
\hline 1 & UD. Ajie Collection & Bloro & Besuki \\
\hline 2 & Hartono Collection & Talkandang & Panarukan \\
\hline
\end{tabular}

Source: Data on UMKM Shellfish Entrepreneur Partners in Situbondo Regency 2017

Shell business "UD. Ajie Collection "was established in the Situbondo Sub-District Situbondo District by Tri Aji Angga, with the decree number 188/099 / BH / XVI.25 / 431.208.2.1 / 2010 issued on 01-07-2010. The business was established using 60 million rupiahs in capital. At the end of December 2016, that business owned Rp. 140,076,000, in assets.

The "Hartono Collection" shellfish business was established by Mr. Hartono, and is located in Talkandang Village, Situbondo District under decree number.188 / 107 / BH / XVI.25 / 431.208.2.1 / 2010 issued on 0107-2010. The initial capital of the business was Rp. 50,000,000 and the present amount of assets owned by the company totals Rp. 215,247,000.

\subsection{Development of Return on Investments in shellfish business in Situbondo Regency}

The development of the return on investment in marine shellfish businesses per year varies significantly. Low business volume, with specific reference to low transaction turnover, reduces the level of income earned by those businesses. The return on investment in the seven cooperatives which are the object of research during 2016, 2017 and 2018 is shown in Table 4.2 below:

Table 4.2 Return on Investment (ROI) for Shellfish in Situbondo Regency 


\begin{tabular}{|c|c|c|c|}
\hline \multirow{2}{*}{$\begin{array}{c}\text { NAME OF PENNGUSION } \\
\text { OF SHELLS }\end{array}$} & \multicolumn{3}{|c|}{ RETURN ON INVESTMEN (ROI) } \\
\cline { 2 - 4 } & Tahun 2016 & Tahun 2017 & Tahun 2018 \\
& $(\%)$ & $(\%)$ & $(\%)$ \\
\hline UD. Ajie Collection & 2,017 & 1,554 & 0,007 \\
\hline Hartono Collection & $-0,865$ & $-0,535$ & $-0,346$ \\
\hline
\end{tabular}

Source: Data on UMKM Shellfish Entrepreneur Partners in Situbondo Regency 2017

Ajie Collection achieved a negative ROI in 2016 and 2017, being -0.865 and -0.535 respectively, whereas in 2018 it experienced a positive ROI of 0.007. Hartono Collection achieved a high ROI in 2015 and 2016 at 2.017 and 1.554 respectively, however, in 2018, its ROI decreased to -0.346 .

The Ajie Collection continues to experience significant growth compared to several other cooperatives. With this growth, the Hartono Collection can continue to drive its level of investment and continue to increase its net income. In contrast, the ROI of Kowan Amirah Mandiri, Sakinah and Seruni Manis continues to decline, which may be due to the small amount of investment in those businesses.

\subsection{Coefficient of Determination (R2)}

The determinant coefficient test results (R2) describe the magnitude of the contribution of the independent variables, namely, total assets (net assets), net sales (net sales), profit after taxes (earnings after taxes) to the dependent variable, namely, the return on investment. The results of the statistical determinant coefficient using SPSS (Statistical Package for the Social Sciences) version 21 can be seen in Table 4.1 below:

\begin{tabular}{|c|c|c|c|c|}
\hline \multicolumn{5}{|c|}{ Table 4.2 Model Summary } \\
\hline Model & R & R Square & Adjusted R Square & $\begin{array}{c}\text { Std. Error of the } \\
\text { Estimate }\end{array}$ \\
\hline 1 & $.813 \mathrm{a}$ & .661 & .634 & $5.83945 \mathrm{E} 8$ \\
\hline
\end{tabular}

Table 4.3 Multiple Linear Regression Test Results

\begin{tabular}{|c|c|c|c|c|c|c|}
\hline \multicolumn{7}{|c|}{ Coefficients } \\
\hline \multirow{2}{*}{\multicolumn{2}{|c|}{ Model }} & \multicolumn{2}{|c|}{ Unstandardized Coefficients } & \multirow{2}{*}{$\begin{array}{c}\text { Standardized } \\
\text { Coefficients } \\
\text { Beta }\end{array}$} & \multirow[b]{2}{*}{$\mathrm{t}$} & \multirow[b]{2}{*}{ Sig. } \\
\hline & & $\mathrm{B}$ & Std. Error & & & \\
\hline \multirow[t]{4}{*}{1} & (Constant) & $5.659 \mathrm{E} 8$ & $1.920 \mathrm{E} 8$ & & 2.948 & .005 \\
\hline & TOTAL AKTIVA & $-1.144 \mathrm{E} 7$ & 2420659.249 & -.537 & -4.725 & .000 \\
\hline & NET SALES & 9755786.700 & 1137563.576 & .976 & 8.576 & .000 \\
\hline & $\begin{array}{c}\text { EARNING AFTER } \\
\text { TAXES }\end{array}$ & 278985.566 & 402083.731 & .069 & .694 & .492 \\
\hline \multicolumn{7}{|c|}{ a. Dependent Variable: RETURN ON INVESTMENT } \\
\hline
\end{tabular}




\section{Conclusion}

The seashells constitute the external cover of bivalves and gastropods and the internal bone of cuttle fish. These shells have both ornamental and medicinal value. In addition to this, these are also used as rich sources of calcium. The oyster shells contain 52-55\% calcium oxide and are used in the manufacture of calcium carbide, lime and cement. The shells crushed to suitable size are used as poultry grit. The shell lime is used for manuring coffee plantations, as a mortar in building constructions, ill the treatment of effluents, as a pesticide for mixing with copper sulphate and in glass, rayon, polyfibre, paper and sugar industries.

This paper makes the following suggestions for shellfish business owners: The businesses must improve their credit services as consumers prefer credit services that are easier to obtain compared to capital or loans. Businesses must make better use of marketing services in order to compete with other shellfish businesses. The management of shellfish businesses must be reliable and must act in the best interests of the business, promoting its development and growth. Hence a comprehensive policy on production, marketing conservation and utilization of all ancillary marine products is essential to optimise employment and economic growth.

\section{References}

Siregar, Shinta M. 2009. Utilization of Seashells and Epoxy Resin on the Characteristics of Polymer Concrete. Thesis Published. Medan: University of North Sumatra.

Cousins, M. 1994. The Ugly. AA files, Autumn, 28, 61-64.

Mediastika, C. E. 2008. Straw as a Raw Material for Wall Coating Acoustics. Dimension of Architectural Engineering XXXVI (1): 20-27.

Betsky, A. and Adigard, E. (2000). Architecture Must Burn. London: Thames \& Hudson. Architecture and Anthropology. (2006). Architectural Design Magazine. Academy Group. Covering and Exposing: The Architecture of Coop Himmelb, 1.

Noerwastiko, V. T. 2001. Alternative Building Materials. Dimension of Architectural Engineering XXIX (2): 134-140. Mangunwijaya, Y. B. (1995). Wastu Citra: Introduction to Culture in the Form of Architecture, Joints of Philosophy and Practical Examples. Jakarta: Main Gramedia Library.

Sathiadhas, R., \& Aswathy, N. (2004). Techno-economic analysis of production and marketing of marine by-products in India. Journal of the Indian Fisheries Association, 31, 155-165. 